\title{
Cell Wall-Associated Virulence Factors Contribute to Increased Resilience of Old Cryptococcus neoformans Cells
}

\author{
Erika P. Orner ${ }^{1 \dagger}$, Somanon Bhattacharya ${ }^{2 \dagger}, K_{l e a} K_{a l e n j a}{ }^{1}$, Danielle Hayden ${ }^{1}$, \\ Maurizio Del Poeta ${ }^{1,2,3}$ and Bettina C. Fries ${ }^{1,2,3 *}$
}

' Department of Microbiology and Immunology, Stony Brook University, Stony Brook, NY, United States, ${ }^{2}$ Department of Medicine, Division of Infectious Disease, Stony Brook University, Stony Brook, NY, United States, ${ }^{3}$ Northport Veterans Affairs Medical Center, Northport, NY, United States

\section{OPEN ACCESS}

Edited by:

Joshua D. Nosanchuk, Albert Einstein College of Medicine,

United States

Reviewed by:

Livia Kmetzsch,

Federal University of Rio Grande do

Sul, Brazil

Marilene Henning Vainstein,

Federal University of Rio Grande do

Sul, Brazil

*Correspondence: Bettina C. Fries

Bettina.Fries@stonybrookmedicine.edu

${ }^{\dagger}$ Co-first authors

Specialty section: This article was submitted to Fungi and Their Interactions, a section of the journal

Frontiers in Microbiology

Received: 29 August 2019 Accepted: 18 October 2019 Published: 07 November 2019

Citation:

Orner EP, Bhattacharya S, Kalenja K, Hayden D, Del Poeta M and Fries BC (2019) Cell Wall-Associated Virulence Factors Contribute to Increased Resilience of Old Cryptococcus neoformans Cells. Front. Microbiol. 10:2513. doi: 10.3389/fmicb.2019.02513
As Cryptococcus neoformans mother cells generationally age, their cell walls become thicker and cell-wall associated virulence factors are upregulated. Antiphagocytic protein 1 (App1), and laccase enzymes (Lac1 and Lac2) are virulence factors known to contribute to virulence of $C$. neoformans during infection through inhibition of phagocytic uptake and melanization. Here we show that these cell-wall-associated proteins are not only significantly upregulated in old $C$. neoformans cells, but also that their upregulation likely contributes to the increased resistance to antifungal and host-mediated killing during infection and to the subsequent accumulation of old cells. We found that old cells melanize to a greater extent than younger cells and as a consequence, old melanized cells are more resistant to killing by amphotericin B compared to young melanized cells. A decrease in melanization of old lac $\Delta$ mutants lead to a decrease in old-cell resilience, indicating that age-related melanization is contributing to the overall resilience of older cells and is being mediated by laccase genes. Additionally, we found that older cells are more resistant to macrophage phagocytosis, but this resistance is lost when APP1 is knocked out, indicating that upregulation of APP1 in older cells is in part responsible for their increased resistance to phagocytosis by macrophages. Finally, infections with old cells in the Galleria mellonella model support our conclusions, as loss of the APP1, $\angle A C 1$, and $L A C 2$ gene ablates the enhanced virulence of old cells, indicating their importance in age-dependent resilience.

Keywords: Cryptococcus neoformans, aging, virulence, antiphagocytic protein, cell wall, melanin

\section{INTRODUCTION}

For a pathogen to survive in a host during infection, it must be able to sense its environment and respond accordingly. In the human host, fungal pathogens can withstand high body temperatures, changes in $\mathrm{pH}$ and nutrient composition, and the host response by modifying their cell wall. Cryptococcus neoformans is a ubiquitous environmental fungus that causes disease in humans who are immune compromised. C. neoformans is responsible for upward of 15\% of AIDS-related deaths worldwide (Rajasingham et al., 2017). During infection, alveolar macrophages are the 
first line of defense against Cryptococcus (Alvarez and Casadevall, 2006). In order to establish an infection, C. neoformans must find a way to inhibit macrophage phagocytosis and phagocytic killing. C. neoformans employs a number of virulence mechanisms to combat macrophage attack including age-dependent cell wall modification (Bouklas et al., 2013), melanization, and secretion of the antiphagocytic protein 1, App1 (Del Poeta, 2004).

Previously, our lab has shown that generational aging of fungi contributes to enhanced resilience in the host (Bouklas et al., 2013, 2017a,b; Bhattacharya and Fries, 2018; Bhattacharya et al., 2019; Orner et al., 2019). C. neoformans, like other yeasts, undergoes asymmetric division when replicating, resulting in a mother cell's phenotype that continuously evolves with each division (Bouklas et al., 2013). Generationally aged cells (i.e., 10-generation-old cells) show an increased resistance to phagocytic ingestion, phagocytic killing, and even antifungal killing (Bouklas et al., 2013, 2017a; Orner et al., 2019). What mediates this age-dependent resilience is not known, but experimental data demonstrates the selection and accumulation of generationally older cells during infection in rats and in humans (Bouklas et al., 2013, 2017a).

Antiphagocytic protein 1 (App1) is a virulence factor that is unique to C. neoformans (Luberto et al., 2003) and located in the cell wall of C. neoformans (Qureshi et al., 2012). This protein is also secreted into the supernatant of cultures and detectable in bronchoalveolar lavage fluid, serum, and cerebral spinal fluid of patients (Luberto et al., 2003; Stano et al., 2009; Williams and Del Poeta, 2011). App1 inhibits phagocytosis by macrophages through a complement-mediated mechanism where the App1 protein competes with $\mathrm{iC} 3 \mathrm{~b}$ for binding to complement receptor (CR) 3 on macrophages (Stano et al., 2009). During infection, iC3b opsonizes microbes and binds to complement receptor 3 on professional phagocytes like monocytes, macrophages, and dendritic cells to aid in phagocytosis (Stuart, 2002). When App1 binds to CR3, it reduces attachment and ingestion of C. neoformans into macrophages both ex vivo and in vitro in a dose-dependent manor (Luberto et al., 2003). Knockout mutants lacking APP1 are less virulent in mice, indicating this virulence factor plays an important role in establishing infection. Interestingly, Qureshi et al. (2012) found App1 to have amyloid properties and argue it may also play additional roles in pathogenesis. For example, amyloids have been shown to help evade the immune system by producing a protective coating around the cell wall in various other microbes (Gebbink et al., 2005; Qureshi et al., 2012). Furthermore, different amyloids have been shown to be important for melanin biosynthesis (Qureshi et al., 2012).

Melanin production is a key virulence factor for a wide variety of microbes and multicellular organisms including fungi, bacteria, plants, and animals (Howard and Valent, 1996; van Duin et al., 2002; Nosanchuk and Casadevall, 2003). Melanin synthesis occurs in the cell wall through the oxidation of phenolic substances like dopamine, epinephrine, and norepinephrine into quinones which then polymerize into pigmented melanin products (Williamson, 1994). These substances are found in high concentrations in the central nervous system and may contribute to C. neoformans' tropism for the central nervous system
(Polacheck et al., 1982). Melanization contributes to resistance against antibody-mediated phagocytosis and phagocytic killing by macrophages (Wang et al., 1995; Casadevall and Perfect, 1998; Zhu and Williamson, 2004) and resistance against free-radical killing by reactive oxygen and nitrogen species (Wang et al., 1995; Missall et al., 2004). Furthermore, melanization provides protection against antifungals like amphotericin $\mathrm{B}$, the first line therapeutic against C. neoformans (van Duin et al., 2002).

The laccase gene, $L A C 1$ encodes the rate-limiting enzyme that catalyzes polymerization of quinones and has been the focus of most C. neoformans melanization studies (Torres-Guererro and Edman, 1994; Williamson, 1994). LAC2 is another cryptococcal laccase gene that exhibits $72 \%$ amino acid homology to $L A C 1$ (Missall et al., 2004). LAC1 has a unique C-terminal motif that localizes the protein to the cell wall of $C$. neoformans at physiological pH (7.4; Waterman et al., 2007). LAC2 is truncated in the C-terminal region and is located in the cytosol under normal conditions but can locate to the cell wall in the absence of LAC1 (Missall et al., 2004). Both LAC1 and LAC2 genes contribute to melanization.

Here, we found that APP1, LAC1, and LAC2 genes are all upregulated old $C$. neoformans cells (10 generations old) compared to young cells (0-2 generations old). Interestingly, all three mutants exhibited shorter median lifespans. Furthermore, our data demonstrates that when knockout mutant strains were aged to 10 generations, they no longer exhibited enhanced agedependent resistance to killing by antifungals, macrophages, or Galleria mellonella worms. Furthermore, we also found that $L A C 2$ is not just a redundant gene to compensate for $L A C 1$, but rather, it contributes to age-dependent resilience distinct from $L A C 1$.

\section{MATERIALS AND METHODS}

\section{Strains and Media}

Strains and sources of strains used in this study are shown in Table 1. All strains were stored in $30 \%$ glycerol at $-80^{\circ} \mathrm{C}$. When needed, strains were struck on Yeast-Peptone-Dextrose (YPD) agar plates (BD), grown at $37^{\circ} \mathrm{C}$ and stored at $4^{\circ} \mathrm{C}$. Media used in this study is listed in Table 2. All liquid cultures were grown at $37^{\circ} \mathrm{C}$, shaking at $150 \mathrm{rpm}$.

\section{Replicative Lifespan and Cell Size Measurement}

The replicative lifespan (RLS) of all strains was determined by traditional microdissection methodology (Bouklas et al., 2013).

TABLE 1 | Strains used in this study.

\begin{tabular}{|c|c|}
\hline Strain & Source \\
\hline H99 & Dr. John Perfect (Duke University) \\
\hline Kn99 $\alpha$ & Dr. Maurizio Del Poeta (Stony Brook University) \\
\hline H99 $а$ арр1 & Dr. Maurizio Del Poeta (Stony Brook University) \\
\hline $\mathrm{H} 99 \Delta \mathrm{lac} 1$ & Dr. Peter Williamson (National Institutes of Health) \\
\hline $\mathrm{Kn} 99 \alpha \Delta \mathrm{lac} 2$ & Dr. Maurizio Del Poeta (Stony Brook University) \\
\hline
\end{tabular}


TABLE 2 | Media used in this study.

\begin{tabular}{|c|c|}
\hline Media & Components per 1 Liter or source \\
\hline Yeast-Peptone-Dextrose (YPD) & BD - Unmodified \\
\hline Sabaroud Dextrose (SAB) & BD - Unmodified \\
\hline Melanization Media (MM) & $\begin{array}{l}4 \mathrm{~g} \mathrm{KH}_{2} \mathrm{PO}_{4}, 2.5 \mathrm{~g} \mathrm{MgSO}_{4} \cdot 7 \mathrm{H}_{2} \mathrm{O}, 0.975 \mathrm{~g} \\
\text { Glycine, } 3 \mathrm{~g} \text { Dextrose, } 1 \mathrm{mg} \text { Thiamine, } 1 \mathrm{mM} \\
\text { L-DOPA }\end{array}$ \\
\hline Synthetic Media (SM) & $\begin{array}{l}1.7 \mathrm{~g} \text { yeast nitrogen base without amino acids, } \\
1 \mathrm{~g} \text { drop out mix, } 0.4 \% \text { ethanol, } 5 \mathrm{~g} \\
\left(\mathrm{NH}_{4}\right)_{2} \mathrm{SO}_{4}, 3.3 \mathrm{~g} \mathrm{NaCl}, 20 \mathrm{~g} \text { glucose }\end{array}$ \\
\hline RPMI 1640 & Gibco - unmodified \\
\hline DMEM & $\begin{array}{l}\text { Gibco - modified with 10\% heat inactivated } \\
\text { Fetal Bovine Serum, 10\% NCTC (Gibco), 1\% } \\
\text { non-essential amino-acids, and 1\% } \\
\text { Penicillin-Streptomycin }\end{array}$ \\
\hline
\end{tabular}

Briefly, 25-30 cells were lined up on a YPD agar plate using a $25 \mu \mathrm{m}$ fiber-optic needle (Cora Styles) on a tetrad dissection Axioscope A1 microscope (Zeiss) and grown at $37^{\circ} \mathrm{C}$. After 1 division, naïve cells were separated from their mothers and designated as starting mother cells. These cells were then tracked and after every division (every 60-120 min), naïve daughter cells were counted and removed to allow the mothers to continue to divide. In between divisions, cells were incubated at either $37^{\circ} \mathrm{C}$ or $4^{\circ} \mathrm{C}$ overnight to slow growth and prevent excessive replication. As cells reached desired generational age, images were taken of the cells on top of an EVOS FL Auto microscope (Thermo Fisher Scientific) and cell sizes were measured using FIJI opensource software.

\section{Isolation of Old Cells}

Previously described methods for isolation of old and young cells were slightly modified (Bouklas et al., 2013). Briefly, exponential cells were washed and labeled with $8 \mathrm{mg} / \mathrm{mL}$ Sulfo-NHS-LC-LCBiotin (Thermo Scientific) for $1 \mathrm{~h}$ at room temperature. After $1 \mathrm{~h}$, cells were washed with PBS and labeled with $20 \mu \mathrm{L}$ anti-biotin (Miltenyi Biotec) per $10^{7}$ cells for $1 \mathrm{~h}$ at $4^{\circ} \mathrm{C}$. After labeling, cells were grown in either sabaroud dextrose (SAB) (Difco) media, melanization media (MM), or synthetic media (SM) as outlined to a specific generation. Recovery of generationally aged mother cells was done using LS magnetic columns (Miltenyi Biotec). The negative fraction that washed off the column was used as the young control group as they were exposed to the same manipulation as old cells retained in the magnetic column.

\section{Quantitative Reverse Transcriptase Polymerase Chain Reaction (qPCR)}

RNA was isolated from both young (0-3 generation) and old (10 generation) cells grown in SAB using Qiagen RNAeasy Kit following manufacturer's guidelines. Nanodrop (Biospectrophotometer, Eppendorf) was used to quantify the isolated RNA. An absorption ratio (A260/A280) of 2.0 was considered pure and good quality RNA. $250 \mathrm{ng}$ of RNA was converted to cDNA using Verso cDNA Kit (Thermoscientific) following manufacturer's guidelines. Oligo-dT was used as the primer for the preparation of cDNA. After this, cDNA was diluted 1:5 with nuclease free water (Hyclone) and subjected to qPCR (Roche) utilizing Power SYBR Green Master Mix (Applied Biosystems) following manufacturer's guidelines. The oligonucleotides used for this assay are listed below. Housekeeping gene ACT1 was used as an internal control. Data was normalized to the gene expression in the young $(0-3$ generation) cells of both wildtype strains. Data was analyzed using $\Delta \Delta \mathrm{Ct}$ method as previously described (Livak and Schmittgen, 2001). The following primers were used:

ACT1: F5'-CCCACACTGTCCCCATTTAC-3', R5'-AACCAC GCTCCATGAGAATC-3'; APP1: F5'-CCAAACTGCGTTACTC AGCA-3', R5' -TAATGCTGCTTTCCCCATTC-3'; LAC1: F5' -TT TGGGTCCGCCCCTTAATTATC-3', R5'-GGATAGGTGCATG AGGAGGA-3'; LAC2: F5'-TATCCTCCTCCCGAGAT-3', R5' GCATCCCCTTCTTTTCCTTC-3'.

\section{Macrophage Phagocytosis and Killing}

J774.16 macrophages were cultured in DMEM (Gibco) media containing 10\% heat inactivated Fetal Bovine Serum (FBS), 10\% NCTC (Gibco), 1\% non-essential amino-acids and 1\% PenicillinStreptomycin. $5 \times 10^{5}$ macrophages/well were plated in 96-well flat-bottomed plate (Costar) and incubated for $24 \mathrm{~h}$ at $37^{\circ} \mathrm{C}$ with $10 \% \mathrm{CO}_{2}$. After $24 \mathrm{~h}$, macrophages were activated with LPS and IFN $\gamma$ as described previously (Jain et al., 2009). After activation, the macrophages were washed three times and fresh DMEM media was added. In separate tubes, $10^{5}$ young ( $0-3$ generations) or old (10 generation) cells from each Cryptococcus strain grown in $\mathrm{SAB}$ were incubated with either $10 \%$ normal human serum (NHS) or 18B7 antibody for $5 \mathrm{~min}$ for opsonization. Opsonized cells were added directly onto the macrophages at a MOI of $1: 1$ and incubated for $1 \mathrm{~h}$ at $37^{\circ} \mathrm{C}$ with $10 \% \mathrm{CO}_{2}$. After $1 \mathrm{~h}$ of phagocytosis, all wells were washed three times with PBS. After $1 \mathrm{~h}$ of phagocytosis and washing, half the wells of macrophages were lysed with sterile water and $C$. neoformans cells were plated on YPD agar plates to determine the number of colony-forming units (CFUs) engulfed at time 0 . In the second half of wells, fresh DMEM was added and cells were allowed to kill any engulfed cells for $1 \mathrm{~h}$ at $37^{\circ} \mathrm{C}$ with $10 \% \mathrm{CO}_{2}$. After $1 \mathrm{~h}$ of killing, macrophages were lysed with sterile water, and surviving C. neoformans cells were plated on YPD agar plates to determine the number of CFUs after phagocytic killing. All YPD plates were incubated for $48 \mathrm{~h}$ at $37^{\circ} \mathrm{C}$. CFUs were counted and percent killing was calculated as $\frac{\text { \# CFU post phagocytosis time } 0-\text { \# CFU time } 1 \mathrm{~h}}{\text { \# CFU post phsgocytosis time } 0} \times 100 \%$.

For phagocytic index, Giemsa staining was used to identify the number of C. neoformans cells in each macrophage. Images of cells were taken with EVOS FL Auto microscope (Thermo Fisher Scientific). Phagocytic index was calculated as \# Cn engulfed $\times 100$ the number of $C$. neoformans cells engulfed by the macrophages divided by the total number of macrophages engulfing the C. neoformans cells multiplied by 100 (Zaragoza et al., 2003).

\section{Galleria mellonella Infection}

Galleria mellonella infection was carried out as previously described (Bouklas et al., 2015). C. neoformans cells grown in SAB were washed and diluted in PBS to $10^{6}$ cells $/ \mathrm{mL}$. $10 \mu \mathrm{L}$ of 
the cell suspension was injected into each G. mellonella worm (Vanderhorst Wholesale Inc., St. Mary's, OH, United States) and 20 worms were used for each strain. One set of 20 worms were injected with PBS as negative control and another set of twenty larvae were neither injected with PBS nor with Cryptococcal cells. This group was used as a quality control for the worms. Survival was noted for a week.

\section{Melanization}

To assess melanization, cells were grown in melanization media (MM) for the specified amount of time. Pigmentation was measured by spinning cells down into a PCR tube and capturing an image of the pellets. Pellet pigmentation was analyzed by histogram analysis on a scale of 0-255 ( $0=$ true black, $255=$ true white) using FIJI opensource software (Schindelin et al., 2012). Melanization between strains was normalized by ensuring the starting culture concentrations and time in MM was the same across all strains.

\section{Antifungal Killing}

Antifungal Killing assays were done as previously described (Jain et al., 2009). Briefly, cells were either melanized and grown in MM or grown in SM. Cells were grown to 10 generations and isolated as described above. The unlabeled fraction served as the young control ( $0-3$ generation) against the 10 generation old cells. Young and old, and melanized and unmelanized cells of all strains were subjected plated in 96 well plates at $10^{4}$ cells $/ \mathrm{mL}$ and were subjected to $0.5 \mu \mathrm{g} / \mathrm{mL}$ of amphotericin B for $3 \mathrm{~h}$. After $3 \mathrm{~h}$, cells were diluted and plated on YPD plates. After plates were incubated for $48 \mathrm{~h}$ at $37^{\circ} \mathrm{C}$, the number of colony forming units (CFUs) were counted and compared to CFUs of plates incubated with no antifungals ( $\%$ killing $=\frac{\# \mathrm{CFU} \text { with drug }}{\# \mathrm{CFU} \text { without drug }}$ ).

\section{Statistics}

Statistical analysis was performed using Graph Pad Prism 6.0 and 8.0. The names of the statistical tests performed for each experiment are listed in the figure legends.

\section{RESULTS}

\section{Upregulation of Genes With Age}

First, we used qPCR to analyze the expression of genes APP1, $L A C 1$, and $L A C 2$ in the young (0-3 generations) and old (10 generation) cells from both wildtype strains H99 and KN99 $\alpha$. All three genes were significantly ( $>$ two-fold) upregulated in old wildtype cells when compared to young cells (Figure 1).

\section{Macrophage Phagocytosis}

Macrophage-mediated phagocytosis assays were performed by opsonizing the fungal cells with either $10 \%$ normal human serum (NHS; Figures 2A,B) or by opsonizing the fungal cells with 18B7 antibody (Ab; Figures 2C,D; Casadevall et al., 1998). As expected, under NHS-mediated opsonization conditions, old wildtype cells were phagocytosed significantly less than young wildtype cells (H99: 185 vs. 292\%, respectively; KN99 $\alpha$ : 242 vs. $392 \%$, respectively). This age-related resistance to phagocytosis is not observed with old cells isolated from the mutants app1 $\Delta$, lac $1 \Delta$, and lac $2 \Delta$. As expected, young app1 $\Delta$ cells exhibited significantly higher phagocytosis compared to wildtype (375 vs. $292 \%$, respectively). In contrast, neither young lac1 $\Delta$ (331\%) nor young lac $2 \Delta(373 \%)$ cells exhibited altered phagocytosis compared to wildtype (H99: 292\%; KN99 2 : 392\%). In contrast, old cells of all three mutants were phagocytized significantly more compared to the old cells of the respective wild type (app1 $\Delta: 386$ vs. $185 \%$; lac1 1 : 373 vs. $185 \%$; lac $2 \Delta$ : 362 vs. $242 \%$ ).

Next, antibody-mediated opsonization was compared. These experiments indicated a significant decrease in phagocytosis of old KN99 $\alpha$ cells when compared to young cells (217 vs. 318\%) and the same trend of impaired phagocytosis of old H99 cells was indicated (202 vs. 289\%). Again, analogous to the NHSmediated opsonization, we did not observe significant differences in phagocytosis between the young and old app1 $\Delta, \operatorname{lac} 1 \Delta$, and lac $2 \Delta$ mutant cells. Unlike NHS-mediated opsonization, no significant differences were observed in phagocytosis of old wildtype and old mutant cells when opsonized with mAb $18 \mathrm{~B} 7$.
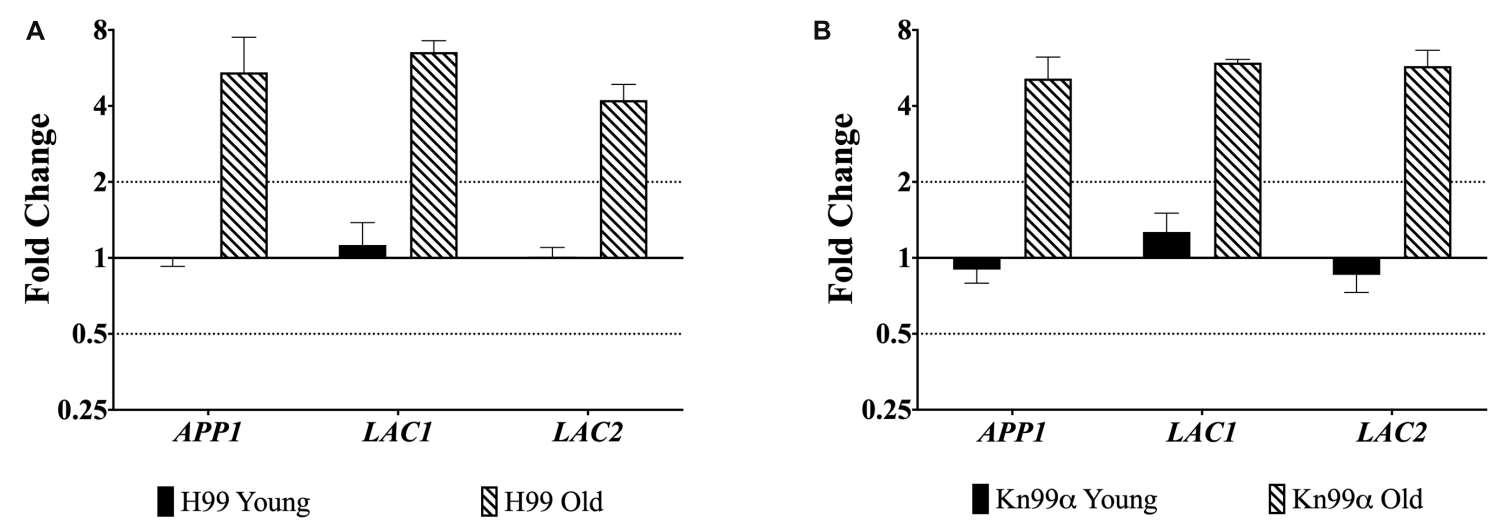

FIGURE 1 | Increased expression of virulence genes in old cells. Expression of genes APP1, LAC1, and LAC2 in young (0-3 generations) and old (10 generations) cells from both wildtype $\mathrm{H} 99$ (A) and KN99 $\mathbf{( B )}$ was analyzed using qPCR. Data was normalized to the gene expression in young cells. Housekeeping gene ACT1 was used as an internal control. Twofold up or twofold downregulation, marked by the dotted lines, was considered a significant fold change difference. Error bars signify standard deviation of technical replicates. 


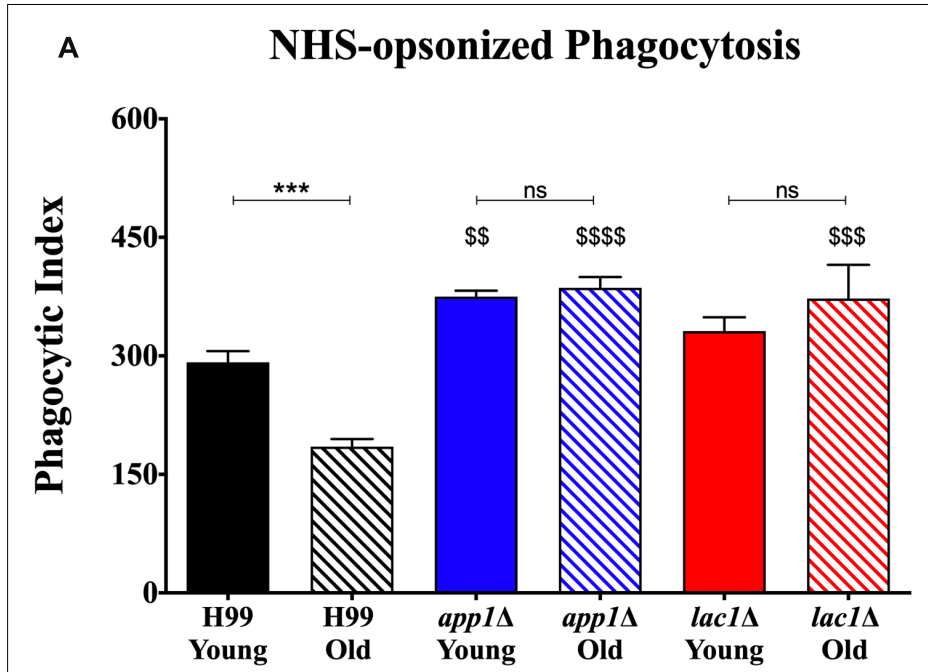

C

Ab-opsonized Phagocytosis

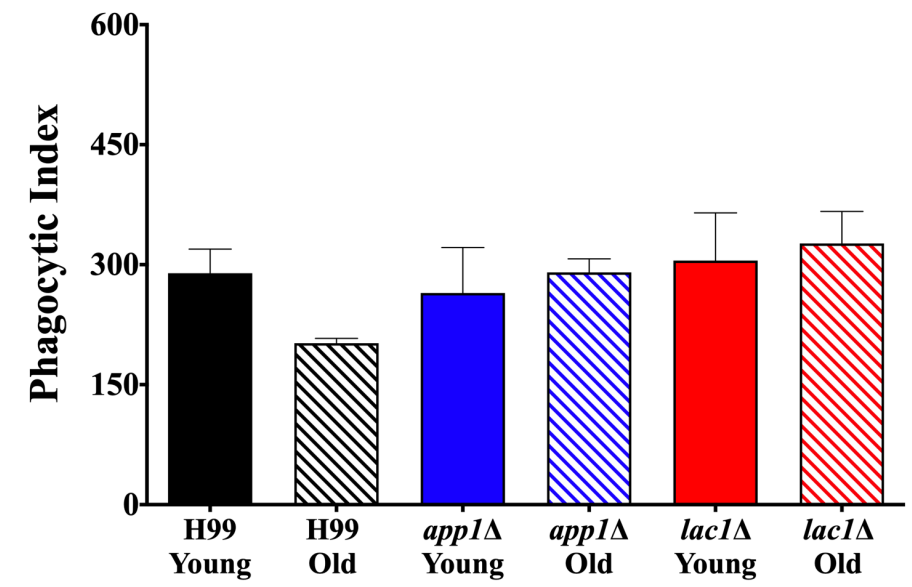

B

NHS-opsonized Phagocytosis

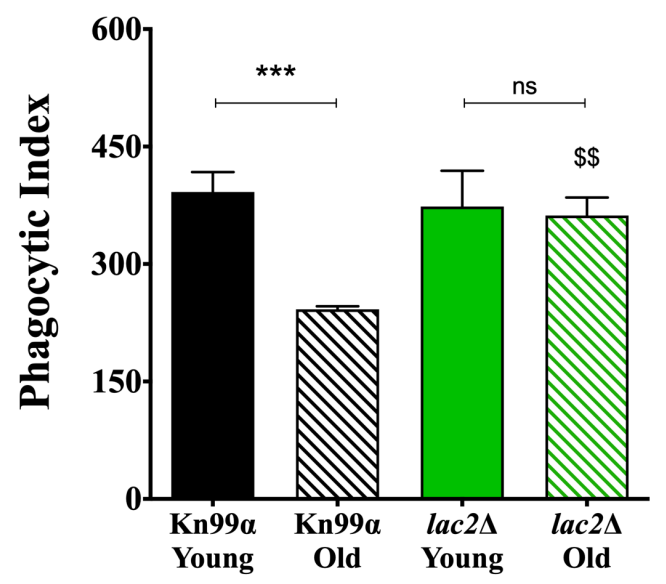

D
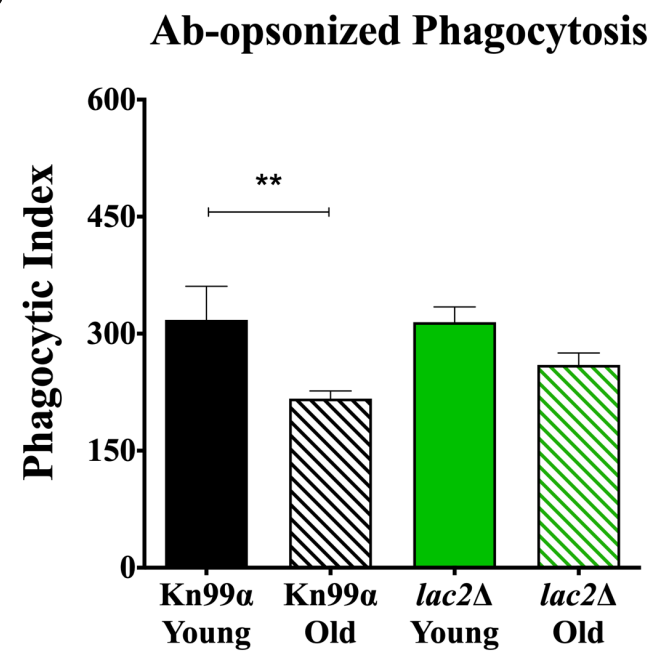

FIGURE 2 | Decreased complement- and antibody-mediated macrophage phagocytosis of old wildtype cells compared to young and mutant cells. Phagocytic index was measured as the number of $C$. neoformans cells engulfed by macrophages divided by the total number of macrophages multiplied by 100 . The assays were performed by opsonization of the fungal cells with $10 \%$ normal human serum (A,B) or by $18 \mathrm{~B} 7$ antibody (C,D). The assays were done in biological triplicate and error bars signify standard deviation between replicates. ${ }^{* *} p<0.01,{ }^{* * *} p<0.001$ by one-way ANOVA. Bars without any ${ }^{*}$ are non-significant. $\$ \$ p<0.01$, $\$ \$ p<0.001, \$ \$ \$ p<0.0001$ by one-way ANOVA when compared to wildtype counterpart.

\section{Macrophage-Mediated Killing}

Since altered phagocytosis can but does not necessarily affect macrophage-mediated killing, both young and old cells isolated from wildtype and mutant strains were subjected to 1-h killing by macrophages and quantification was corrected for the altered phagocytosis index. As expected, a decrease in macrophagemediated killing was observed for NHS-opsonized old cells compared to young cells of both H99 (35 vs. 65\%, Figure 3A) and KN99 $\alpha$ ( 40 vs. $65 \%$, Figure 3B). Similar to wildtype, NHSopsonized, old lac1 $\Delta$ and lac2 $\Delta$ mutant cells also showed a significant decrease in macrophage-mediated killing (lac1 $\Delta$ : 36 vs. $61 \%$; lac $2 \Delta$ : 40 vs. $82 \%$ ). However, no significant change in macrophage-mediated killing was observed between old and young app $1 \Delta$ cells (51 vs. $68 \%$ ).
In contrast, antibody opsonization did not result in a significant difference in killing between young and old cells for any strain (Figures 3C,D) suggesting that serum mediated uptake may play a more important role in the observed age-related loss of resistance in mutants.

\section{Virulence in Galleria mellonella}

Next, we studied the effects of aging in these mutants in the Galleria infection model. Each larva was infected with $10^{4}$ cells as outlined in the materials and methods. Larvae infected with old wildtype cells survived less days than the larvae infected with young wildtype cells (5 vs. 6 days, Figure 4, and Table 3). No significant change in survival was observed in the larvae infected with young vs. old mutant cells. Similarly, no significant 


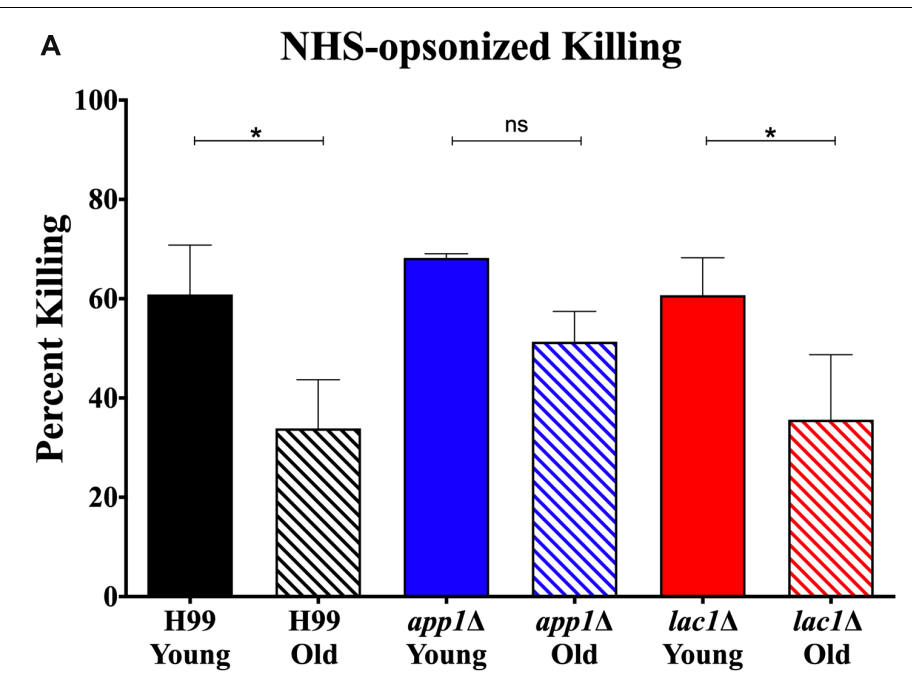

C

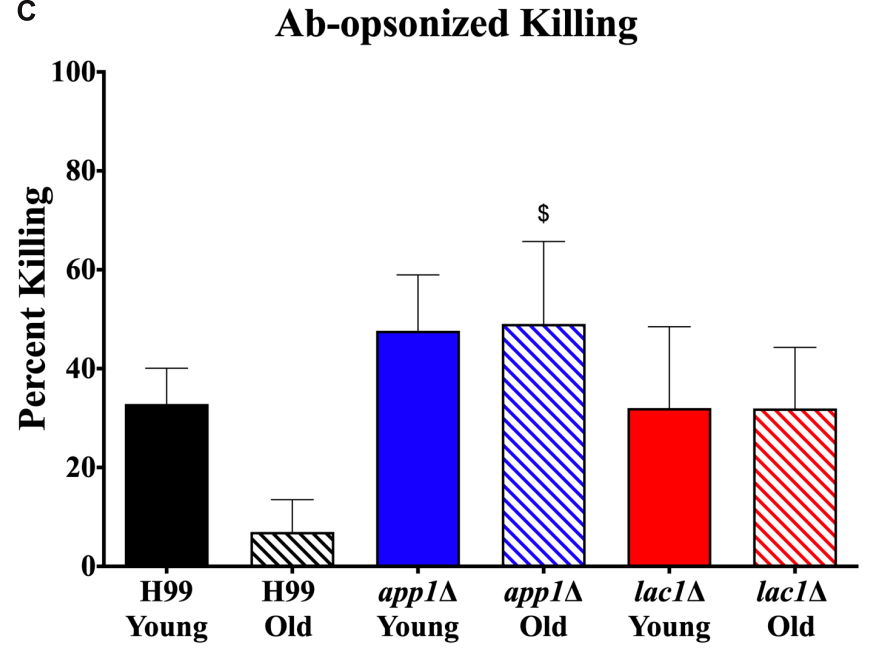

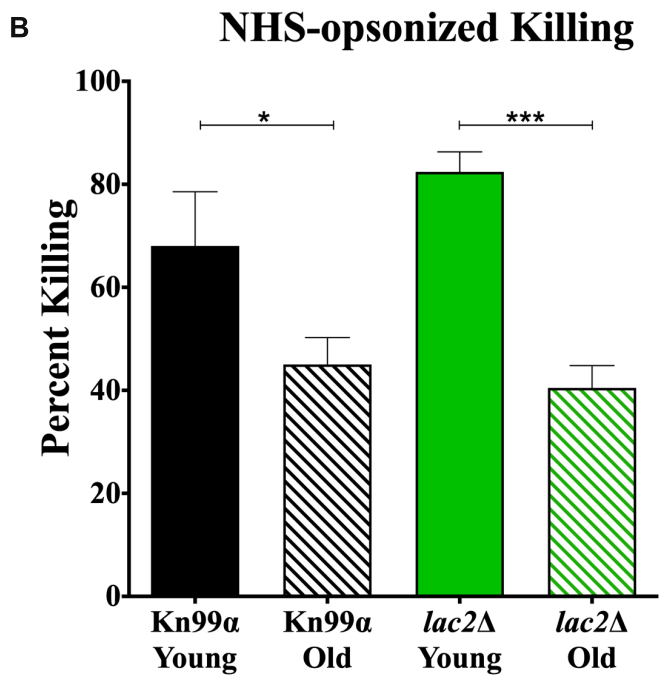

D

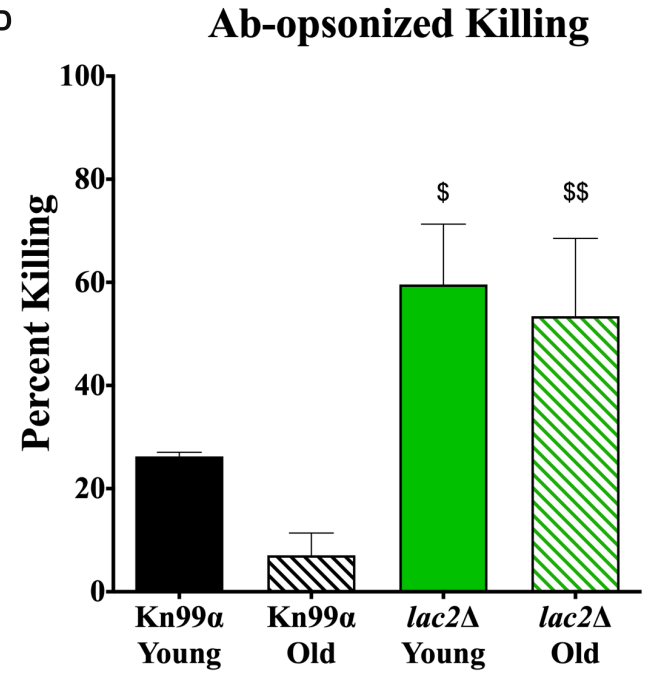

FIGURE 3 | Altered complement-mediated macrophage killing of old cells and mutant cells. Phagocytized cells were incubated for $1 \mathrm{~h}$ in macrophages to allow for phagocytic killing. Surviving C. neoformans cells were plated on YPD agar plates and CFUs were counted after $48 \mathrm{~h}$ incubation at $37^{\circ} \mathrm{C}$ and normalized to CFUs at time 0 before $1 \mathrm{~h}$ of killing. C. neoformans cells were opsonized with $10 \%$ normal human serum (A,B) or by $18 \mathrm{~B} 7$ antibody (C,D). Assays were done in biological triplicate and error bars signify standard deviation between replicates. One-way ANOVA was performed to analyze the statistical significance. ${ }^{*} p<0.05$, ${ }^{* * *} p<0.001$ by one-way ANOVA. ${ }^{\$} p<0.05, \$ \$ p<0.01$ by one-way ANOVA compared to wildtype counterpart.

differences were observed in the survival of the larvae infected with young wildtype cells vs. young mutant cells. Consistent with the loss of impaired phagocytic uptake and killing of mutants, we observed decreased virulence of old mutant cells compared to their respective wildtype aged cells. Specifically, significant differences were observed in survival of the larvae infected with old H99 vs. old app1 $\Delta$ cells (5 vs. 6 days) and old H99 vs. old lac $1 \Delta$ cells ( 5 vs. 6 days). Similarly, a significant difference was observed in survival of larvae infected with the old KN99 $\alpha$ cells vs. old lac $2 \Delta$ cells (5 vs. 7 days).

\section{Melanization}

In order to quantify melanization, cell pellets were assessed using histogram analysis to determine intensity values on a black to white scale. On such a black to white intensity scale, true black has an intensity value (IV) of 0 and true white has an IV of 255. When strains were aged in melanization media, old cells melanized to a higher degree than the young, negative fraction (Figures 5A-D). Young app1 $\Delta(\mathrm{IV}=152)$ and lac2 $\Delta(\mathrm{IV}=150)$ cells melanized to the same degree as young wildtype cells (IV = 147 for both H99 and $\mathrm{Kn} 99 \alpha)$ whereas young lac1 $\Delta$ cells $(\mathrm{IV}=208)$ were closer to unmelanized cells (IV = 231). H99 old (62) and young (147) cells showed a shift of 85 in magnitude and Kn99 $\alpha$ old (103) and young (147) cells showed a shift of 44 in magnitude. None of the mutant strains had as large of a difference in IV as their respective wildtype strains. Compared to H99, app1 $\Delta$ young (152) and old (106) cells only showed a shift of 46 in magnitude and lac1 $\Delta$ young (208) and old (150) cells showed a shift of 58 in magnitude. 


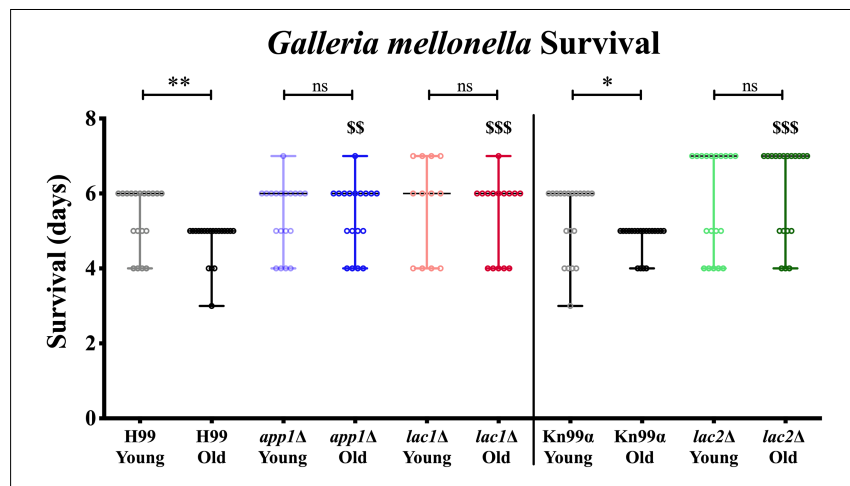

FIGURE 4 | Young cells and mutant strains are less virulent in Galleria mellonella. 106/ $\mathrm{ml}$ cells were injected each in 20 Galleria larvae and survival was noted for 7 days. ${ }^{*} p<0.05,{ }^{* *} p<0.01$ by log-rank test. ${ }^{\$} p<0.01$, $\$ \$ p<0.001$ by log-rank test compared to wildtype counterpart.

lac $2 \Delta$ young (150) and old (125) cells showed the smallest shift of all strains with only a shift of 25 in magnitude.

\section{Antifungal Killing}

Since melanization increases resistance to amphotericin B (AMB), we assessed if melanization in old cells further enhances this resistance. Yeast cells were subjected to $3 \mathrm{~h}$ of killing by $0.5 \mu \mathrm{g} / \mathrm{mL}$ of $\mathrm{AMB}$, a concentration 4 -fold higher than minimum inhibitory concentration (MIC) for all strains (MIC $=0.0625 \mu \mathrm{g} / \mathrm{mL}$, data not shown). These data confirm findings of previous studies (van Duin et al., 2002) that melanization augments resistance to AMB in wildtype young cells (H99 unmelanized $=36.64 \%$, melanized $=71.01 \%$ survival; Kn99 $\alpha$ unmelanized $=28.69 \%$, melanized $=65.44 \%$ survival $)$. Importantly, melanization markedly increases the enhanced resistance of older cells relative to young melanized cells (H99 $\mathrm{Y}=71.01 \%, \mathrm{O}=97.65 \%$ survival; $\mathrm{Kn} 99 \alpha \mathrm{Y}=65.44 \%, \mathrm{O}=77.39 \%$ survival) (Figure 5E).

Old app1s cells, exhibited significantly less resistance to AMB than old wildtype cells (26.96 vs. 57.04\% survival, respectively). Melanization, however, significantly enhanced antifungal resistance of young and old app1s mutant cells. Interestingly there was no significant difference between young and old melanized app1 $\Delta$ cells ( 74.65 vs. $87.36 \%$, respectively).

As expected lac1 $\Delta$ mutant cells exhibited minimal melanization. Hence, no difference between unmelanized young and melanized young lac1s cells was noted. The minimally melanized old lac $1 \Delta$ cells were therefore significantly more susceptible than melanized old wildtype cells (42.01 vs. 97.65\% survival, respectively).

Similar to lac1 $\Delta$ cells, there was no significant difference between young and old unmelanized lac $2 \Delta$ cells or between young and old melanized lac2 $\Delta$ cells. Melanization of lac2 $\Delta$ cells did, however, increase the resistance of young cells $(65.82$ vs. $37.92 \%$ survival, respectively) and old cells (65.46 vs. $42.50 \%$ survival, respectively). Lastly, also similar to lac1 $\Delta$ cells, old melanized lac $2 \Delta$ cells were more susceptible than old melanized wildtype cells ( 65.46 vs. $77.39 \%$ survival, respectively).

\section{Replicative Lifespan and Cell Size}

In order to determine whether the changes in susceptibility seen with age were associated with changes in lifespans or cell size, we determined the replicative lifespan (RLS) (Figure 6A) and assessed the size of mutants and wildtype cells (Figure 6B). All mutant strains exhibited shortened median RLS compared to wildtype (Figure 6C). This was most pronounced for app1 $\Delta$ cells, which had a median RLS of 21.5 generations (33.9\% loss). Both lac $1 \Delta$ cells and lac2 $\Delta$ cells also exhibited shorter lifespans $(16.1 \%$ loss, and $17.6 \%$ loss, respectively).

In all strains a significant increase in cell size was observed with advanced generational age (H99 $\mathrm{Y}=4.736 \mu \mathrm{m}$, $\mathrm{O}=6.824 \mu \mathrm{m} ; \operatorname{app} 1 \Delta \mathrm{Y}=4.952 \mu \mathrm{m}, \mathrm{O}=6.424 \mu \mathrm{m}$; lac1 $\Delta \mathrm{Y}=5.732 \mu \mathrm{m}, \mathrm{O}=7.399 \mu \mathrm{m} ; \mathrm{Kn} 99 \alpha \mathrm{Y}=5.444 \mu \mathrm{m}$, $\mathrm{O}=7.162 \mu \mathrm{m} ; \operatorname{lac} 2 \Delta \mathrm{Y}=4.894 \mu \mathrm{m}, \mathrm{O}=8.259 \mu \mathrm{m})$ (Figure 6D). Furthermore, lac1 $\Delta$ cells were larger at young and old age compared to wild-type and lac2 $\Delta$ cells were also significantly larger at old age compared to wildtype. Interestingly, no significant difference between young wildtype and app1 $\Delta$ cells, or old wildtype and app1 $\Delta$ cells was noted despite the significantly shortened lifespan of app $1 \Delta$ cells. Similarly, young lac $2 \Delta$ cells were significantly smaller than wildtype despite the significantly shortened lifespan.

\section{Gene Regulation With Age in Mutants}

qPCR was used to evaluate potential compensation between laccase genes in the respective mutant. Though old lac1 $\Delta$ mutant cells showed increased expression of LAC2 compared to young lac1 $\Delta$ cells (4.51-fold vs. 1.09-fold, Figure 7A), the expression of $L A C 2$ in old lac1 $\triangle$ mutant cells was much lower than the expression of LAC2 in old wildtype cells (4.51-old vs. 15.75fold, Figure 7A). Similarly, old lac $2 \Delta$ cells showed increased expression of $L A C 1$ when compared to young cells (2.13-fold vs. 0.83 -fold, Figure 7B) and the expression of LAC1 in old lac2 $\triangle$ cells was much lower than $L A C 1$ expression in old wildtype cells (2.13-fold vs. 4.23-fold, Figure 7B). Importantly, these results suggest that $L A C 2$ expression in old lac1 $\triangle$ cells is higher than $L A C 1$ expression in lac $2 \Delta$ cells.

\section{DISCUSSION}

Previous studies have demonstrated that generationally older C. neoformans accumulate during infection, and are more virulent, and more resistant to antifungals (Bouklas et al., 2013, 2017b). This may result from a thickened cell wall, increased cell size, or upregulation of drug exporters in generationally old cells. In this study, we analyzed the roles of three cell-wall-associated proteins, App1, Lac1, and Lac2, in age-dependent virulence and antifungal tolerance in $C$. neoformans. Their transcription was significantly upregulated in 10-generation old cells, suggesting the importance of these proteins in generationally old cells.

$A P P 1$ encodes for an antiphagocytic protein and provides protection to the fungal cells against macrophage phagocytosis. As expected, the phagocytic index of young app1s cells was significantly lower compared to the phagocytic index of young wildtype cells. This confirms previous results which 
TABLE 3 | Young cells and mutant strains are less virulent in Galleria mellonella.

\begin{tabular}{|c|c|c|c|c|c|}
\hline Strain name & Age & Galleria survival (Median) days & $P$-value & Significance & Remarks \\
\hline \multirow[t]{2}{*}{$\mathrm{H} 99$} & Y & 6 & \multirow[t]{2}{*}{0.0015} & \multirow[t]{2}{*}{ S } & \multirow[t]{2}{*}{ Aging significantly increased virulence } \\
\hline & $\mathrm{O}$ & 5 & & & \\
\hline \multirow[t]{2}{*}{ lac1 $\Delta$} & Y & 6 & \multirow[t]{2}{*}{0.55} & \multirow[t]{2}{*}{ NS } & \multirow[t]{2}{*}{ Age-associated increased virulence disappeared } \\
\hline & $\mathrm{O}$ & 6 & & & \\
\hline \multirow[t]{2}{*}{ app1s } & Y & 6 & \multirow[t]{2}{*}{0.55} & \multirow[t]{2}{*}{ NS } & \multirow[t]{2}{*}{ App1 important in age-dependent resilience } \\
\hline & $\mathrm{O}$ & 6 & & & \\
\hline H99 & Y & 6 & \multirow[t]{2}{*}{0.0943} & \multirow[t]{2}{*}{ NS } & \multirow[t]{2}{*}{ Lac2 compensates for Lac1 in young cells } \\
\hline lac1 $1 \Delta$ & $\mathrm{Y}$ & 6 & & & \\
\hline H99 & $\mathrm{Y}$ & 6 & \multirow[t]{2}{*}{0.5238} & \multirow[t]{2}{*}{ NS } & \multirow[t]{2}{*}{ App1 works via complement and Galleria lacks full complement system } \\
\hline app1s & $\mathrm{Y}$ & 6 & & & \\
\hline H99 & $\mathrm{O}$ & 5 & \multirow[t]{2}{*}{0.0002} & \multirow[t]{2}{*}{ S } & \multirow[t]{2}{*}{ Lac2 failed to compensate for loss of Lac1 in old age } \\
\hline lac1s & $\mathrm{O}$ & 6 & & & \\
\hline H99 & $\mathrm{O}$ & 5 & \multirow[t]{2}{*}{0.0022} & \multirow[t]{2}{*}{ S } & \multirow[t]{2}{*}{ App1 needed for age-dependent virulence } \\
\hline app1 $1 \Delta$ & $\mathrm{O}$ & 6 & & & \\
\hline \multirow[t]{2}{*}{ KN99 $\alpha$} & $\mathrm{Y}$ & 6 & \multirow[t]{2}{*}{0.004} & \multirow[t]{2}{*}{ NS } & \multirow[t]{2}{*}{ Aging significantly increased virulence } \\
\hline & $\mathrm{O}$ & 5 & & & \\
\hline \multirow[t]{2}{*}{ lac2 $\Delta$} & Y & 7 & \multirow[t]{2}{*}{0.47} & \multirow[t]{2}{*}{ NS } & \multirow[t]{2}{*}{ Lac2 important in age-dependent resilience } \\
\hline & $\mathrm{O}$ & 7 & & & \\
\hline $\mathrm{KN} 99 \alpha$ & $\mathrm{Y}$ & 6 & \multirow[t]{2}{*}{0.02} & \multirow[t]{2}{*}{ NS } & \multirow[t]{2}{*}{ Lac1 compensates for Lac2 in young cells } \\
\hline lac2 $\Delta$ & Y & 7 & & & \\
\hline KN99 $\alpha$ & $\mathrm{O}$ & 5 & 0.0004 & S & Lac1 failed to compensate for loss of lac2 in old age \\
\hline lac2 $\Delta$ & $\mathrm{O}$ & 7 & & & \\
\hline
\end{tabular}

identify APP1 as an important player in preventing phagocytosis (Luberto et al., 2003). The phagocytic index for 10 -generationold, NHS-opsonized wildtype cells was significantly lower compared to young wild type cells. However, old app1 $\Delta$ cells exhibited no significant difference in the phagocytic index when compared to that of young app1 $\Delta$ cells. The phagocytic index for 10-generation-old, Ab-opsonized wildtype cells was also lower compared to young wild type cells. However, there was no significant difference in the phagocytic index between app1 $\Delta$ and wildtype cells. This difference between complement- and antibody-mediated phagocytosis is likely due to the fact that App1 inhibits phagocytosis by a complement-mediated and not an Ab-mediated mechanism.

App1 is similarly important in preventing macrophagemediated killing of generationally older cells. Old wildtype cells are killed significantly less than young cells, however, we found no significant difference in macrophage-mediated killing of young and old app $1 \triangle$ cells. This is true for both Ab-opsonized and NHSopsonized cells. Thus up-regulation of APP1 in generationally older C. neoformans cells contributes to both the decreased phagocytosis and decreased macrophage-mediated killing in generationally older cells in vitro.

We found further support for these findings in vivo in the G. mellonella insect model. Although, Galleria do not have a true complement system they utilize complement-like proteins (Tsai et al., 2016). Survival of Galleria worms infected with app1 $\Delta$ cells was not altered by aging whereas older wildtype cells killed the worms faster. This finding is consistent with the in vitro killing assays and further indicates that App1 is an important virulence factor that contributes to enhanced resilience of older generation of cells.
In addition to the role of App1 in inhibiting phagocytosis and macrophage-mediated killing, Qureshi et al. (2012) hypothesized that App1 may also play a role in melanization as it has amyloid properties and amyloids have been shown to play a role in melanin biosynthesis in other species. Interestingly, we found that young app1 $\Delta$ cells melanized to the same extent as wildtype cells, whereas old app1 $\Delta$ cells exhibited lower levels of melanization compared to old wildtype cells. Regardless, melanization of both young and old app1 $\Delta$ cells increased their resistance to $\mathrm{AMB}$ killing.

Of interest, App1 seems to play a role in age-dependent resistance to AMB as old unmelanized app $1 \Delta$ cells do not survive significantly more than young unmelanized cells and in fact, the old app1 $\Delta$ cells survive significantly less than old wildtype cells. Furthermore, though melanization enhances app1 $\Delta$ cells resistance against $\mathrm{AMB}$ killing, there is still no significant difference between young and old melanized $a p p 1 \Delta$ cells. Future studies are required to determine whether loss of App1 alters cell wall structure as App1 is located in the cell wall (Qureshi et al., 2012). If true, it would be interesting to further explore if such changes in the cell wall's composition may also have an effect on the cell membrane, which is below the cell wall. Others have described that changes in cell membrane affect the cell wall and alter its sensitivity to caspofungin and congo red, which target the cell wall (Mesa-Arango et al., 2016; Bhattacharya et al., 2018).

In addition to $A P P 1$, we studied the effects of the laccase enzyme encoding genes $L A C 1$ and $L A C 2$ on age-dependent resilience. Lac1 typically localizes in the cell wall but it is highly $\mathrm{pH}$ dependent. In $C$. neoformans cells located in the brain (physiological $\mathrm{pH}$ around 7.2-7.4), Lac1 is almost exclusively found in the cell wall. At lower $\mathrm{pHs}$, however, such as $\mathrm{pH}$ 
A

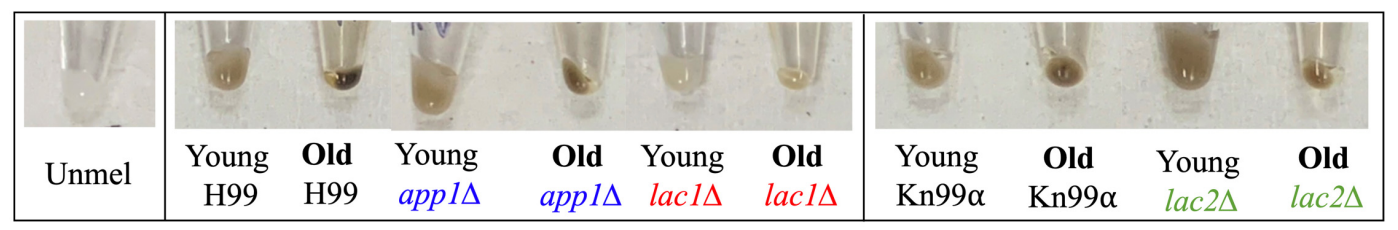

B

app1s Melanization c lac1s Melanization
D

lac2 $\Delta$ Melanization

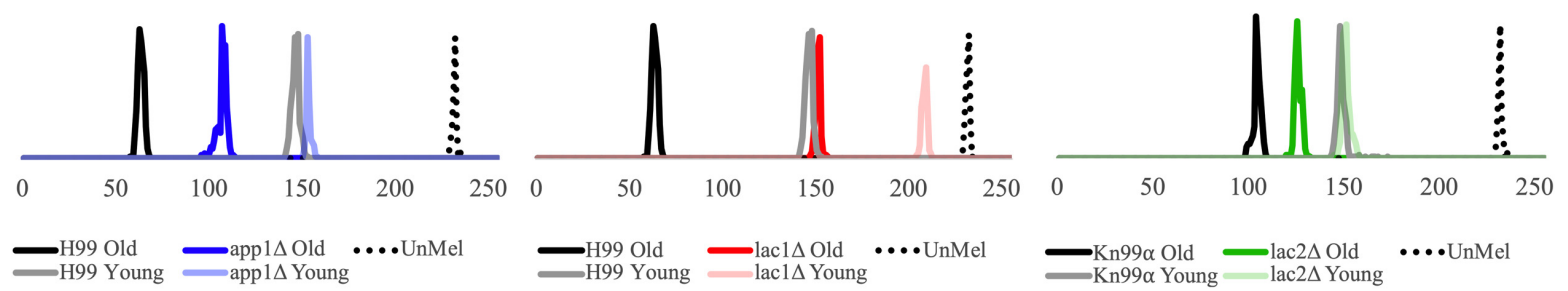

E

\section{Survival in $3 \mathrm{~h}$ of $0.5 \mu \mathrm{g} / \mathrm{mL}$ AMB}

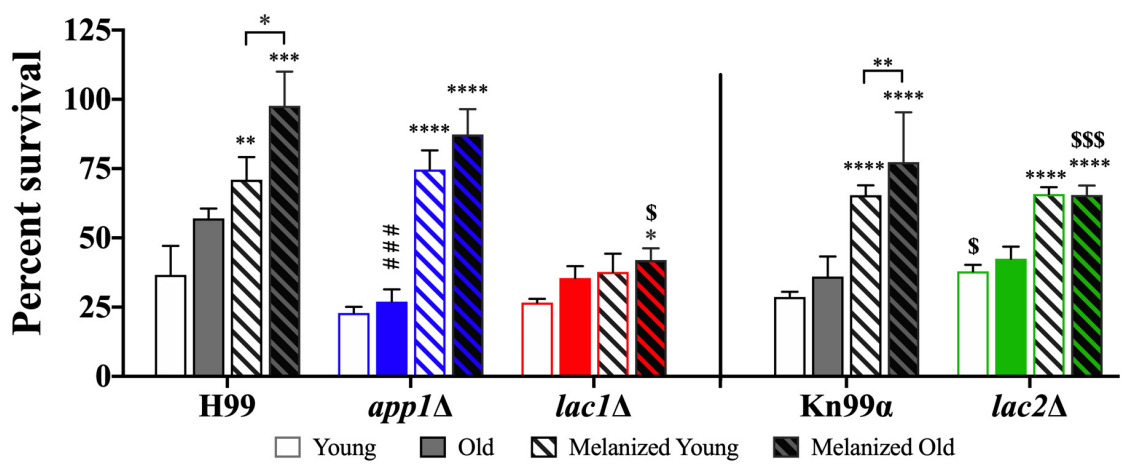

FIGURE 5 | Melanization increases with age which enhances antifungal resistance. Wildtype and mutant cells were aged to 10 generations in melanization media. Old cells were separated from the young, negative fraction and melanization was compared by imaging cell pellets (A) and quantifying darkness using black to white histogram analysis (on a scale from 0 to 255. 0, true black, 255, true white). Melanization of young and old fractions of app1 $\Delta$ (B), lac1 $\Delta$ (C), and lac2 $\Delta$ (D) were compared to melanization of young and old fractions of their respective wildtype strains. Fractions of young and old cells from each strain grown in control and melanization media were subjected to $3 \mathrm{~h}$ of killing by $0.5 \mu \mathrm{g} / \mathrm{mL}$ AMB (E). Percent survival was calculated for each population which was then normalized to the young wildtype strain grown in control media. ${ }^{*} p<0.05,{ }^{* *} p<0.01,{ }^{* * *} p<0.001,{ }^{* * *} p<0.0001$ by one-way ANOVA compared to young cells of the same strain grown in control media. ${ }^{\$} p<0.05,{ }^{\$ \$} p<0.001$ by one-way ANOVA compared to wildtype counterpart.

of 5 as seen in macrophages, Lacl tends to get trapped in cytoplasmic vesicles (Waterman et al., 2007). Interestingly, it has been shown that Lac1 plays an important role in extrapulmonary dissemination to the brain but it does not contribute to pulmonary survival or persistence (Noverr et al., 2004). Lac2 is a protein similar to Lac1 and both of them play an important role during melanization. For this study, we obtained the mutant strains lacking $L A C 1$ and $L A C 2$.

First, we assessed whether LAC1 or LAC2 are important in macrophage phagocytosis. No significant difference in phagocytosis between young wildtype and mutant cells was documented. Old lac1 $\Delta$ and lac $2 \Delta$ cells, however, were phagocytized significantly more than old wildtype cells indicating both $L A C 1$ and $L A C 2$ are important in the age-dependent resilience to macrophage phagocytosis. This was observed for NHS-opsonized cells but not Ab-opsonized cells, suggesting that age-dependent resilience to phagocytosis mediated by $L A C 1$ and $L A C 2$ may be through a complement-mediated mechanism.
Because $L A C 1$ and $L A C 2$ play a role in phagocytosis, we then assessed whether LAC1 and LAC2 were important for macrophage-mediated killing. Both wildtype and mutant populations were more resistant to macrophage killing when aged compared to respective young populations. When cells were opsonized with antibody, however, old lac1 $\Delta$ lost their agedependent resilience as they were killed at the same rate as young lac1 $\Delta$ cells. Furthermore, both young and old lac $2 \Delta$ were killed at higher rates compared to their respective wildtype populations and old lac2 $\Delta$ cells lost their age-dependent resilience to killing compared to their young counterparts. Taken together, both $L A C 1$ and $L A C 2$ seem to play a role in age-dependent resilience to phagocytic killing but only when opsonized by antibody and not complement. Furthermore, LAC2 may play an important role in resistance against antibody-mediated phagocytic killing.

To further analyze the virulence of the lac1s and lac2 $\Delta$ mutants in vivo, young and old mutant cells were injected into 
A

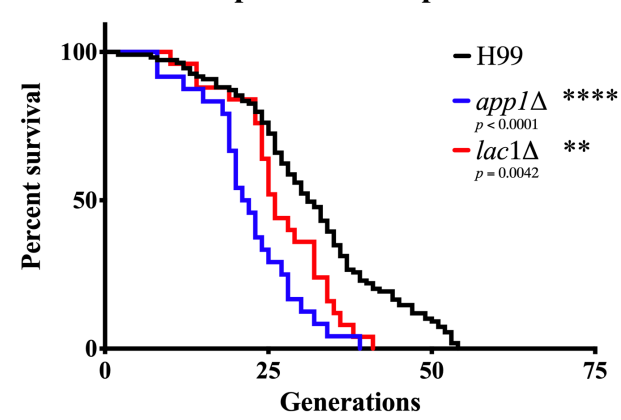

C

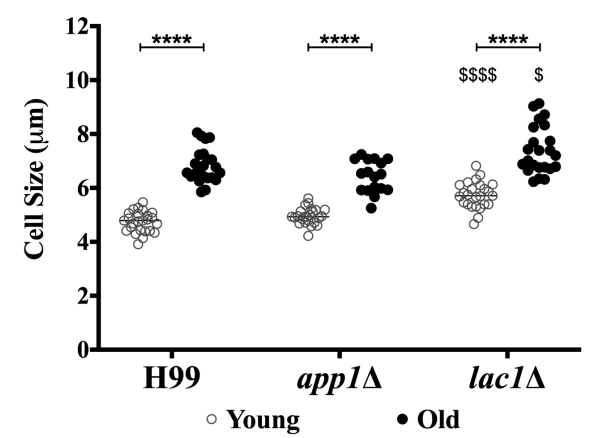

B

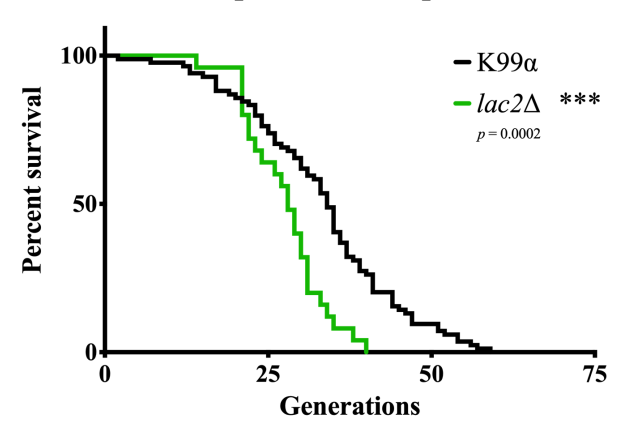

D

Replicative Lifespan

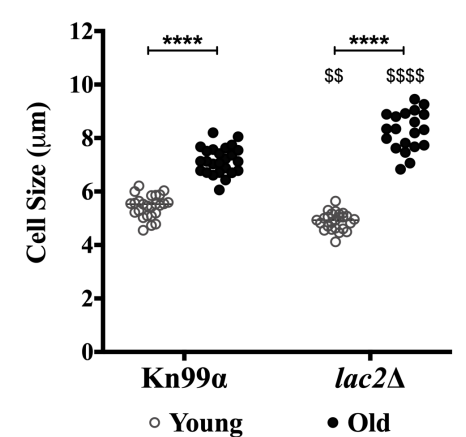

FIGURE 6 | Decreased lifespan of mutants and increased cell size with age. Replicative lifespans were determined for each mutant strain and compared to its respective wildtype (A,B). Cell sizes were measured in the young ( $0-3$ generations) and old (10 generations) fractions of cells after separation to assess the cell size of each population (C,D). ${ }^{* *} p<0.01,{ }^{* * *} p<0.001,{ }^{* * * *} p<0.0001$ by one-way ANOVA. ${ }^{\$} p<0.05,{ }^{\$} p<0.01$, ${ }^{\$ \$ \$} p<0.0001$ by one-way ANOVA compared to wildtype counterpart.
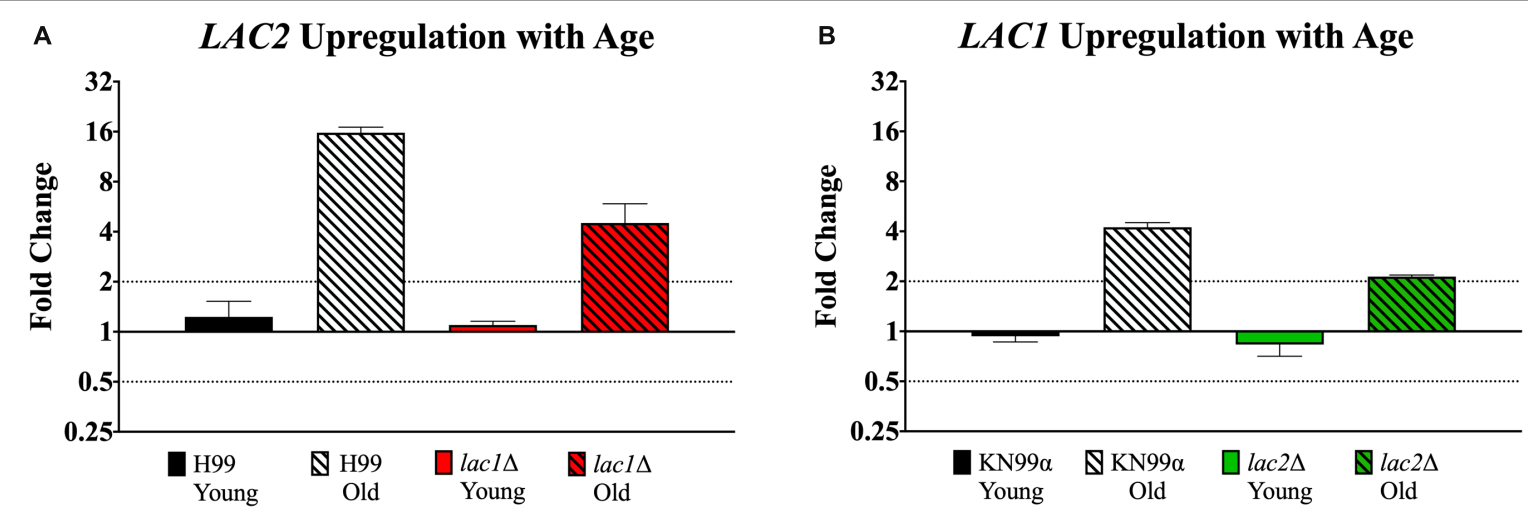

FIGURE 7 | Increased expression of $L A C 1$ and $L A C 2$ genes in old cells. Expression of LAC2 in young (0-3 generations) and old (10 generations) wildtype H99 and lac1 $\Delta$ cells (A). Expression of LAC1 in young (0-3 generations) and old (10 generations) wildtype KN99 $\alpha$ and lac2 $\Delta$ cells (B). Data was normalized to the gene expression in young cells. Housekeeping gene ACT1 was used as an internal control. Twofold up or twofold downregulation, marked by the dotted lines, was considered a significant fold change difference. Error bars signify standard deviation of technical replicates.

Galleria and survival was assessed. Overall, we observed no significant changes in virulence between young mutants and young wildtype cells. This suggests, in conjunction with our phagocytosis results, that in young cells, Lac1 and Lac2 may be compensating for each other when one gene is absent. However, significant changes in age-dependent virulence were observed.
Both $\operatorname{lac} 1 \Delta$ and $\operatorname{lac} 2 \Delta$ mutant populations showed a loss of age-dependent virulence as both young and old populations of either mutant strain killed Galleria at the same rate. Furthermore, old lac1 $\Delta$ and $\operatorname{lac} 2 \Delta$ cells were significantly less virulent than wildtype old cells, further indicating Lac1 and Lac2 are important in mediating age-dependent resilience. 
Since the most important role of Lac1 and Lac2 is melanization, we analyzed melanization in young and old lac1 $\Delta$ and lac $2 \Delta$ cells and compared them with their respective wildtypes. As expected, loss of either LAC1 or LAC2 reduced the ability of cells to melanize. Previously it was thought that LAC1 was the main contributor and LAC2 served a less important, redundant role (Missall et al., 2004). This is likely because previous studies only focused on young cultures. Looking at generationally older cells, we see LAC2 plays an important role in melanization at older ages. lac1 $\Delta$ mutant cells do not melanize well overall, but old cells are able to melanize to a greater extent (shift of $58 \mathrm{IV}$ units between young and old) compared to lac2 $\Delta$ mutant cells (shift of 25 IV units between young and old). Furthermore, when young and old melanized cells were subjected to AMB for $3 \mathrm{~h}$, old lac1s mutant cells were $11.4 \%$ more resistant to killing compared to young. There was no difference, however, in resistance of old and young lac $2 \Delta$ mutant cells (65.5 vs. $65.58 \%$, respectively). Taken together, LAC2 may partially compensate for loss of $L A C 1$ in old age. The loss of resistance to AMB in old laccase mutant cells may again be explained by altered composition to the cell wall as seen in the app1s mutant cells. However, Lac2 is not typically found in the cell wall unless Lac1 is missing so altered cell wall composition in the mutants cannot be the only factor contributing to this loss of $\mathrm{AMB}$ resistance in old age.

Since we observed that each of these genes play a significant role in age-dependent resistance, we asked the question whether App1, Lac1, or Lac2 play any role in altering the replicative life span of C. neoformans. In C. neoformans, strains can only undergo a finite number of divisions before senescence, the cumulative total of which is termed the replicative lifespan (RLS) (Bouklas et al., 2013). When the RLS of a strain is shifted in either direction, the relative age of a 10-generation old cell shifts and the respective age-dependent resilience is altered (Bouklas et al., 2017b). When a wildtype strain lives to be on average 30 generations, 10 generations is one third it's lifespan. If that strain is mutated and its average RLS shifts to only 20 generations, a 10 -generation old cell is now through half of its lifespan making it relative older. We have shown previously that this decrease in RLS also alters the strains age-dependent resilience as 10 generation cells from the mutant with a shortened RLS are more resistant to macrophage killing than 10-generation wildtype cells (Bouklas et al., 2017b). To ensure the loss in age-dependent resistance of our mutant strains was not solely due to a shift in RLS, we determined RLS of each mutant. All three mutants exhibited decreased median RLSs compared to their respective wildtypes. Since 10-generation cells of all mutants are relatively older than their wildtype counterparts, their age-dependent resilience should be higher than the wildtype. Similarly, 10generation old mutant cells are as large or significantly larger than 10-generation wildtype cells. Taken together, we conclude the decrease and loss in age-dependent resilience of mutant strains is likely not due to the change in RLS or their cell size.
Though it is difficult to hypothesize why these virulence factors affect RLS, it has been found that APP1 transcription is controlled by diacylglycerol (DAG) through the transcription factor ATF2 (Mare et al., 2005). In C. neoformans, DAG also activates Pkcl (Heung et al., 2004), and Pkcl regulates Laccase (Heung et al., 2005) and Sir2 silencing (Lee et al., 2013) (an ageregulating gene). Thus, increased DAG would increase activation of App1 through Atf2, as well as Laccase activity and Sir2 silencing through $\mathrm{Pkc1}$, which could result in more App1 being secreted, increased melanization, and longer replicative lifespan. Future studies to investigate these potential mechanisms are planned to discern the common pathway(s) that regulate these genes and their transcription factors to better understand how they contribute to age-dependent resilience.

In conclusion, App1, Lac1, and Lac2 each play a significant role in age-dependent resilience and regulation of replicative life span. App1 is more important for age-dependent resistance against NHS-mediated phagocytosis and killing and AMB killing. Lac1 and Lac2 are more important for age-dependent resistance against Ab-mediated killing, AMB killing, and age-dependent melanization. Furthermore, our data suggest that both Lac1 and Lac2 are needed in generationally old cells. This study thus identifies some of the key-players that contribute to agedependent resilience of $C$. neoformans.

\section{DATA AVAILABILITY STATEMENT}

The raw data generated and analyzed in this study will be made available by the authors to any qualified researcher by request.

\section{AUTHOR CONTRIBUTIONS}

$\mathrm{EO}, \mathrm{SB}$, and $\mathrm{BF}$ contributed to the design of the study, and drafting and editing of the manuscript. MD also contributed to the reading and editing of the manuscript. $\mathrm{EO}, \mathrm{SB}, \mathrm{KK}$, and $\mathrm{DH}$ contributed to acquisition and analysis of the data.

\section{FUNDING}

This work was supported in part by Dr. Fries' Stony Brook University start-up fund, in part by NIH awards R01-AI059681 and T32AI007539, in part by NIH R01 AI125770, and in part by Merit Review grant I01BX002624 from the Veterans Affairs Program.

\section{ACKNOWLEDGMENTS}

We would like to thank the MD and the Williamson laboratories for their gracious gifting of strains used in this study. We also would like to thank Michael Motley for helping us edit the final manuscript and the Stony Brook Medical Scholars Program for their support. 


\section{REFERENCES}

Alvarez, M., and Casadevall, A. (2006). Phagosome extrusion and host-cell survival after Cryptococcus neoformans phagocytosis by macrophages. Curr. Biol. 16, 2161-2165. doi: 10.1016/j.cub.2006.09.061

Bhattacharya, S., Esquivel, B. D., and White, T. C. (2018). Overexpression or deletion of ergosterol biosynthesis genes alters doubling time, response to stress agents, and drug susceptibility in Saccharomyces cerevisiae. mBio 9:e1291-18. doi: $10.1128 / \mathrm{mBio} .01291-1218$

Bhattacharya, S., and Fries, B. C. (2018). Enhanced efflux pump activity in old Candida glabrata cells. Antimicrob. Agents Chemother. 62:e2227-17. doi: 10. 1128/aac.02227-2217

Bhattacharya, S., Holowka, T., Orner, E. P., and Fries, B. C. (2019). Gene duplication associated with increased fluconazole tolerance in Candida auris cells of advanced generational age. Sci. Rep. 9:5052. doi: 10.1038/s41598-01941513-41516

Bouklas, T., Alonso-Crisóstomo, L., Székely, T. Jr., Diago-Navarro, E., Orner, E. P., Smith, K., et al. (2017a). generational distribution of a Candida glabrata population: resilient old cells prevail, while younger cells dominate in the vulnerable host. PLoS Pathog. 13:e1006355. doi: 10.1371/journal.ppat.10 06355

Bouklas, T., Jain, N., and Fries, B. C. (2017b). Modulation of replicative lifespan in Cryptococcus neoformans: implications for virulence. Front. Microbiol. 8:98. doi: $10.3389 /$ fmicb. 2017.00098

Bouklas, T., Diago-Navarro, E., Wang, X., Fenster, M., and Fries, B. C. (2015). Characterization of the virulence of Cryptococcus neoformans strains in an insect model. Virulence 6, 809-813. doi: 10.1080/21505594.2015.108 6868

Bouklas, T., Pechuan, X., Goldman, D. L., Edelman, B., Bergman, A., and Fries, B. C. (2013). Old Cryptococcus neoformans cells contribute to virulence in chronic cryptococcosis. mBio 4:e455-13. doi: 10.1128/mBio. 00455-413

Casadevall, A., Cleare, W., Feldmesser, M., Glatman-Freedman, A., Goldman, D. L., Kozel, T. R., et al. (1998). Characterization of a murine monoclonal antibody to Cryptococcus neoformans polysaccharide that is a candidate for human therapeutic studies. Antimicrob. Agents Chemother. 42, 1437-1446. doi: 10.1128/aac.42.6.1437

Casadevall, A., and Perfect, J. R. (1998). Cryptococcus neoformans. Washington, DC: ASM Press.

Del Poeta, M. (2004). Role of phagocytosis in the virulence of Cryptococcus neoformans. Eukaryot. Cell 3, 1067-1075. doi: 10.1128/EC.3.5.1067-1075.2004

Gebbink, M. F., Claessen, D., Bouma, B., Dijkhuizen, L., and Wosten, H. A. (2005). Amyloids-a functional coat for microorganisms. Nat. Rev. Microbiol. 3, 333-341. doi: 10.1038/nrmicro1127

Heung, L. J., Kaiser, A. E., Luberto, C., and Del Poeta, M. (2005). The role and mechanism of diacylglycerol-protein kinase $\mathrm{C} 1$ signaling in melanogenesis by Cryptococcus neoformans. J. Biol. Chem. 280, 28547-28555. doi: 10.1074/jbc. M503404200

Heung, L. J., Luberto, C., Plowden, A., Hannun, Y. A., and Del Poeta, M. (2004). The sphingolipid pathway regulates $\mathrm{Pkcl}$ through the formation of diacylglycerol in Cryptococcus neoformans. J. Biol. Chem. 279, 21144-21153. doi: $10.1074 /$ jbc.M312995200

Howard, R. J., and Valent, B. (1996). Breaking and entering: host penetration by the fungal rice blast pathogen Magnaporthe grisea. Ann. Rev. Microbiol. 50, 491-512. doi: 10.1146/annurev.micro.50.1.491

Jain, N., Cook, E., Xess, I., Hasan, F., Fries, D., and Fries, B. C. (2009). Isolation and characterization of senescent Cryptococcus neoformans and implications for phenotypic switching and pathogenesis in chronic cryptococcosis. Eukaryot. Cell 8, 858-866. doi: 10.1128/ec.00017-19

Lee, S., Gaspar, M. L., Aregullin, M. A., Jesch, S. A., and Henry, S. A. (2013). Activation of protein kinase C-mitogen-activated protein kinase signaling in response to inositol starvation triggers Sir2p-dependent telomeric silencing in yeast. J. Biol. Chem. 288, 27861-27871. doi: 10.1074/jbc.M113.49 3072

Livak, K. J., and Schmittgen, T. D. (2001). Analysis of relative gene expression data using real-time quantitative PCR and the 2(-delta delta $\mathrm{C}(\mathrm{T}))$ method. Methods 25, 402-408. doi: 10.1006/meth.2001.1262
Luberto, C., Martinez-Mariño, B., Taraskiewicz, D., Bolaños, B., Chitano, P., Toffaletti, D. L., et al. (2003). Identification of App1 as a regulator of phagocytosis and virulence of Cryptococcus neoformans. J. Clin. Invest. 112, 1080-1094. doi: 10.1172/JCI18309

Mare, L., Iatta, R., Montagna, M. T., Luberto, C., and Del Poeta, M. (2005). APP1 transcription is regulated by inositol-phosphorylceramide synthase 1diacylglycerol pathway and is controlled by ATF2 transcription factor in Cryptococcus neoformans. J. Biol. Chem. 280, 36055-36064. doi: 10.1074/jbc. M507285200

Mesa-Arango, A. C., Rueda, C., Roman, E., Quintin, J., Terron, M. C., Luque, D., et al. (2016). Cell wall changes in amphotericin b-resistant strains from Candida tropicalis and relationship with the immune responses elicited by the host. Antimicrob. Agents Chemother. 60, 2326-2335. doi: 10.1128/aac.026812615

Missall, T. A., Lodge, J. K., and McEwen, J. E. (2004). Mechanisms of resistance to oxidative and nitrosative stress: implications for fungal survival in mammalian hosts. Eukaryot. Cell 3, 835-846. doi: 10.1128/ec.3.4.835-846. 2004

Nosanchuk, J. D., and Casadevall, A. (2003). The contribution of melanin to microbial pathogenesis. Cell. Microbiol. 5, 203-223. doi: 10.1046/j.1462-5814. 2003.00268.x

Noverr, M. C., Williamson, P. R., Fajardo, R. S., and Huffnagle, G. B. (2004). CNLAC1 is required for extrapulmonary dissemination of Cryptococcus neoformans but not pulmonary persistence. Infect. Immun. 72, 1693-1699. doi: 10.1128/iai.72.3.1693-1699.2004

Orner, E. P., Zhang, P., Jo, M. C., Bhattacharya, S., Qin, L., and Fries, B. C. (2019). High-throughput yeast aging analysis for cryptococcus (HYAAC) microfluidic device streamlines aging studies in Cryptococcus neoformans. Commun. Biol. 2:256. doi: 10.1038/s42003-019-0504-505

Polacheck, I., Hearing, V. J., and Kwon-Chung, K. J. (1982). Biochemical studies of phenoloxidase and utilization of catecholamines in Cryptococcus neoformans. J. Bacteriol. 150, 1212-1220.

Qureshi, A., Williams, V., and Del Poeta, M. (2012). Expression and characterization of Cryptococcus neoformans recombinan. App1. Mycopathol. 173, 395-405. doi: 10.1007/s11046-011-9486-9487

Rajasingham, R., Smith, R. M., Park, B. J., Jarvis, J. N., Govender, N. P., Chiller, T. M., et al. (2017). Global burden of disease of HIV-associated cryptococcal meningitis: an updated analysis. Lancet Infect. Dis. 17, 873-881. doi: 10.1016/ s1473-3099(17)30243-30248

Schindelin, J., Arganda-Carreras, I., Frise, E., Kaynig, V., Longair, M., Pietzsch, T., et al. (2012). Fiji: an open-source platform for biological-image analysis. Nat. Methods 9, 676-682. doi: 10.1038/nmeth.2019

Stano, P., Williams, V., Villani, M., Cymbalyuk, E. S., Qureshi, A., Huang, Y., et al. (2009). App1: an antiphagocytic protein that binds to complement receptors 3 and 2. J. Immunol. 182, 84-91. doi: 10.4049/jimmunol. 182.1.84

Stuart, M. L. (2002). Receptor-mediated recognition of Cryptococcus neoformans. Nippon Ishinkin Gakkai Zasshi 43, 133-136. doi: 10.3314/jjmm. 43.133

Torres-Guererro, H., and Edman, J. C. (1994). Melanin-deficient mutants of Cryptococcus neoformans. J. Med. Vet. Mycol. 32, 303-313. doi: 10.1080/ 02681219480000381

Tsai, C. J.-Y., Loh, J. M. S., and Proft, T. (2016). Galleria mellonella infection models for the study of bacterial diseases and for antimicrobial drug testing. Virulence 7, 214-229. doi: 10.1080/21505594.2015.1135289

van Duin, D., Casadevall, A., and Nosanchuk, J. D. (2002). Melanization of Cryptococcus neoformans and Histoplasma capsulatum reduces their susceptibilities to amphotericin B and caspofungin. Antimicrob. Agents Chemother. 46, 3394-3400. doi: 10.1128/aac.46.11.3394-3400. 2002

Wang, Y., Aisen, P., and Casadevall, A. (1995). Cryptococcus neoformans melanin and virulence: mechanism of action. Infect. Immun. 63, 3131-3136.

Waterman, S. R., Hacham, M., Panepinto, J., Hu, G., Shin, S., and Williamson, P. R. (2007). Cell wall targeting of laccase of Cryptococcus neoformans during infection of mice. Infect. Immun. 75, 714-722. doi: 10.1128/iai.013511356 
Williams, V., and Del Poeta, M. (2011). Role of glucose in the expression of Cryptococcus neoformans antiphagocytic protein 1. App1. Eukaryot. Cell 10, 293-301. doi: 10.1128/EC.00252-210

Williamson, P. R. (1994). Biochemical and molecular characterization of the diphenol oxidase of Cryptococcus neoformans: identification as a laccase. J. Bacteriol. 176, 656-664. doi: 10.1128/jb.176.3.656-664.1994

Zaragoza, O., Taborda, C. P., and Casadevall, A. (2003). The efficacy of complement-mediated phagocytosis of Cryptococcus neoformans is dependent on the location of C3 in the polysaccharide capsule and involves both direct and indirect C3-mediated interactions. Eur. J. Immunol. 33, 1957-1967. doi: 10.1002/eji.200323848

Zhu, X., and Williamson, P. R. (2004). Role of laccase in the biology and virulence of Cryptococcus neoformans. FEMS Yeast Res. 5, 1-10. doi: 10.1016/j.femsyr. 2004.04.004
Conflict of Interest: MD is the co-founder and Chief Scientific Officer (CSO) of MicroRid Technologies, Inc.

The remaining authors declare that the research was conducted in the absence of any commercial or financial relationships that could be construed as a potential conflict of interest.

Copyright (C) 2019 Orner, Bhattacharya, Kalenja, Hayden, Del Poeta and Fries. This is an open-access article distributed under the terms of the Creative Commons Attribution License (CC BY). The use, distribution or reproduction in other forums is permitted, provided the original author(s) and the copyright owner(s) are credited and that the original publication in this journal is cited, in accordance with accepted academic practice. No use, distribution or reproduction is permitted which does not comply with these terms. 